This is an author produced version of a paper published in Forest Ecology and Management. This paper has been peer-reviewed and is proof-corrected, but does not include the journal pagination.

Citation for the published paper:

Marine Elbakidze \& Per Angelstam. (2007) Implementing sustainable forest management in Ukraine's Carpathian mountains: the role of traditional village systems. Forest Ecology \& Management. Volume: 249 Number: 1, pp 28-38. http://dx.doi.org/10.1016/j.foreco.2007.04.003

Access to the published version may require journal subscription. Published with permission from: Elsevier

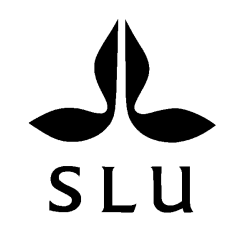

Epsilon Open Archive http://epsilon.slu.se 


\title{
Implementing sustainable forest management in Ukraine's Carpathian Mountains: The role of traditional village systems
}

\author{
Marine Elbakidze (a,b), Per Angelstam (b), \\ a Ivan Franko National University, Department of Physical Geography, Doroshenko str. 41, 79020 Lviv, Ukraine \\ b Swedish University of Agricultural Sciences, Faculty of Forest Sciences, School for Forest Engineers, P.O. Box \\ 43, SE-739 21 Skinnskatteberg, Sweden
}

Published 2007 in Forest ecology and management 249, 28-38

\begin{abstract}
Maintenance of socio-cultural values and biodiversity at local and regional levels are new important additional criteria for the implementation of sustainable forest management. Ukraine's forest sector is in transition from planned socialist to market economy. We evaluated the role of the traditional village system, which was successful for centuries for achieving both common economic as well as these new dimensions of sustainable forest management in Ukraine's Carpathian Mountains.We used the Skole district as a case study that represents one of the most forested areas in Ukraine, and an integral part of Boiko people's ethnographic area. The village is a traditional social-ecological system defined by the traditional land use of pre-industrial cultural landscapes, and a spatial structure with land use zones satisfying different needs. Using documents on regional environmental history, analysis of socio-economic statistics, and interviews with local land users, we evaluated the extent to which the traditional village system supports socio-cultural dimensions of sustainable forest management. Our review of environmental history indicates that after different phases of cultural landscape development during several 100 years, the traditional village system is still a basic unit of the Skole district's forest landscapes. However, data and interviews show that the traditional village system is endangered. Making use of the total economic value of forest landscape resources, including wood and non-wood products and services based on cultural values and biodiversity, is an urgent task. Support of traditional village socio-cultural functions and land use systems including fields, wooded grasslands and forests should be milestones in a regional program of sustainable forest management. Traditional village system zoning and land use systems would be good indicators of sustainable forest landscapes.
\end{abstract}

Keywords: Forest and woodland landscape; Social and cultural sustainability; Rural development; Traditional land use; Cultural landscape; Forest policy

\section{Introduction}

Sustainable forest management (SFM) is a concept in continuous development, the interpretation of which varies over time, as well as among countries, regions and even local landscapes in Europe (e.g., Kennedy et al., 2001; Angelstam et al., 2005). As a consequence, the knowledge required to realise SFM is heterogeneous, and dependent on sets of values with different spatial and temporal scale dimensions (Innes and Hoen, 2005). The development of the Pan-European forest policy process reflects this (Ilavsky, 2006). Moving into the postindustrial society, ecological dimensions became included in the definition of SFM in the 1990s (Angelstam et al., 2004; Rametsteiner and Mayer, 2004). More recently also the role of the social and cultural aspects of SFM in the overall goal of sustainable development, including the role of traditional forest-related knowledge has been highlighted (MCPFE, 2003; Parrotta et al., 2006).

Forests and woodlands have been shaped based on people's traditional knowledge long before the development of industrial forestry. A significant proportion of the world's forests and woodlands are still managed by local and indigenous communities (Stevens, 1997). Such cultural landscapes are usually based on a traditional village system (TVS) with centre-periphery zoning from houses, gardens, fields, mowed and grazed grasslands to forests (i.e. the ancient system with domus, hortus, ager, saltus and silva) (Sporrong, 1998; UNESCO, 1999; Mikusinski et al., 2003; Elbakidze and Angelstam, 2006; http://www.isere-environnement.fr/pages/ index/id/5077). This land use system is thus closely connected to forest and woodland ecosystems. The TVS 
carries traditional knowledge, innovations and practices of indigenous and local communities, gained over long time and adapted to the local culture and environment. TVSs help to sustain production of multiple goods and services providing livelihoods security and quality of life, as well as contribute to characteristic natural and cultural heritage (Angelstam et al., 2003; Agnoletti, 2006; Parrotta et al., 2006). Thus, the traditional village system integrates economic, ecological and socio-cultural dimensions of forest and woodland landscapes in space and time (e.g., Bourguignon, 2006). Cultural heritage and traditional knowledge of TVSs have been recognised and promoted at a global level in a number of international agreements, processes and programmes. At the European level political commitments highlight the importance of increasing the awareness of the role of traditional knowledge supporting SFM practices that contribute to the protection of landscapes and biological diversity (MCPFE, 2003; Rametsteiner and Mayer, 2004). Similarly, the EU Forest Action Plan (European Union, 2006) acknowledged cultural landscapes, traditional practices and other cultural values of forests, as some of the ways of achieving local and regional sustainable development. Such landscape values are also included in the new Common Agricultural Policy (CAP), and the European Landscape Convention (Anon., 2000). However, the traditional village system with its characteristic cultural landscape is threatened by socioeconomic and technological changes in agriculture, industrial forestry and by some nature conservation strategies (Antrop, 2005; Angelstam, 2006). As noted by MCPFE (2003) applied research on the social and cultural aspects of SFM to support the development of solutions to these challenges requires approaches where human and natural science methods are used and where academic and non-academic actors formulate problems together (e.g., Gibbons et al., 1994). We argue that Europe's diverse forest and woodland landscapes is a valuable "landscape laboratory", which can be used to better understand the perceptions of SFM among actors at different levels of governance and role of traditional village systems for implementing sustainable forest management in actual landscapes. The transition from socialist planned to market economy in post-Soviet countries of the European East is of particular and paramount interest for forest sector development in Europe (e.g., Nilsson and Shvidenko, 1999; Krott et al., 2000; Angelstam et al., 2005; Birot et al., 2005; Nilsson, 2005; UNECE, 2005; Ilavsky, 2006; Tornianen et al., 2006; Nordberg, 2007).

Ukraine reappeared as an independent new state in 1991 following the break-up of the Soviet Union. Located in the geographical centre of Europe with both zonal and azonal forest ecoregions (Mayer, 1984), Ukraine represents a globally relevant range of gaps to be bridged to develop the sustainable forest management discourse in actual landscapes. To promote sustainability on national as well as regional and local levels Ukraine has joined the process of developing forest management ideas and principles oriented towards sustainable yield forestry, maintenance of forest biodiversity and socio-cultural values (e.g., Balashenko et al., 2005). As a country in transition, it is very important to evaluate the heritage in forestry and woodland use from the previous socio-economic systems for understanding what should be changed or remain under the new political and economic conditions. The Carpathian Mountain ecoregion, which is represented in the western part of Ukraine, is a good example (Turnock, 2002).

The Ukrainian Carpathians cover 3.5\% of Ukraine's area and 10.3\% of total area of the Carpathian Mountains. This region has forest resources of high economic value, and has retained both cultural and natural biodiversity, and many of Europe's last wilderness areas (Turnock, 2002; Angelstam, 2006). The ecoregion is also home to several ethnographic groups of Ukrainians - Lemko, Boiko and Hutzul - who have been shaping mountain landscapes for centuries and have created a rich cultural heritage (Anon., 1983; Hajda, 1998). Nowadays people in many parts of the Ukrainian Carpathians have experienced decreased standards of living due to disintegration of the planned economy developed during socialism and ongoing transition to market economy under acute political and economic crisis in the country. The picture is, however, very complex, especially as most of the Carpathian ecoregion has been part of Austria-Hungary, Poland and the Soviet Union during the past centuries. On the one hand the Carpathian ecoregion is under severe threat from unsustainable logging methods, past replacement of natural tree species with introduced Norway spruce (Picea abies), habitat loss and fragmentation due to intensified forestry and infrastructure development (Gensiruk, 1964; Trokhimchuk, 1968). On the other hand, due to economic reasons and the need to develop local livelihoods, local people have had to come back to their traditional land use practices of the village system (Elbakidze and Angelstam, 2006). These were commonly practised before socialism and played an important role for maintenance of biodiversity and cultural heritage, and thus rural development in the Ukrainian Carpathians for centuries. The recent privatisation of land that began after the collapse of the socialist system in 1991 has led to a revival of the social and cultural value of forests in Western Ukraine, which often were an unbroken part of families' cultural and natural heritage for generations (Huntingdon, 1996).

This study focuses on the role of the traditional village system to support sustainable forest management in local forest and woodland landscapes. The traditional village system is defined by the land uses of pre- 
industrial cultural landscapes, and a spatial structure with zones of land satisfying different needs. Analysing the regional environmental history, regional statistic socio-economic data and documents and based on interviews with local land users, we evaluated the extent to which this village system has been retained. The study is part of a transdisciplinary research network using multiple case studies located in regions with different biophysical conditions, economic history and systems of governance in Europe's East and West (Angelstam and Tornblom, 2004; Angelstam and Elbakidze, 2006a,b).

\section{Materials and methods}

\subsection{Research methodology}

Working with a complex concept such as sustainable forest management (SFM) requires special emphasis on finding a common theoretical platform for inclusion of ecological, economic, socio-cultural values (e.g., Sastamoinen, 2005), including the related scientific disciplines, and societal actors balancing these values between policy to practice. We use the landscape concept as a theoretical platform of our research. Landscape is an important concept within humanities (history), social sciences (human geography) as well as in natural sciences (ecology and physical geography) (e.g., Forman, 1995; Angelstam, 1997; Grodzinski, 2005; Angelstam and Elbakidze, 2006a). The landscape concept can thus be used as an interface for improving communication between social and natural sciences, as well as between policy and users to increase the understanding of the dependencies between social and ecological systems that make up landscapes.

In the European Landscape Convention "landscape” is defined as a zone or area as perceived by local people or visitors, where the visual features and characters of the landscape are the result of the action of natural and/or cultural factors (Anon., 2000). This definition reflects the idea that landscapes evolve through time. Individual landscapes can be viewed as units that offer a sense of place to stakeholders, thus representing a wide range of issues of concern and solutions. The landscape concept also reflects the need to expand the spatial scale of management, i.e. to move from smaller spatial units or objects to the scale of landscapes and regions, i.e. include micro, meso and macro levels. Additionally, all social organisational scales must be considered, from individual, household or family, to community, county, nation and global. To study the process of implementing sustainable forest management policies we must view natural and socio-cultural components in a temporally and spatially expanded context, and one less restricted by administrative and political boundaries. Thus, we consider that a forest landscape forms a whole entity, where natural and cultural components are intermingled, and cannot be viewed as separate entities or processes.

A landscape is thus a social-ecological system that includes both tangible and intangible values, which can be described using variables that represent all dimensions of SFM (Andersson et al., 2005; Berkes et al., 2003). In an increasingly globalised world, it is essential to understand how factors at local, regional, national and international levels affect the future development of sustainable forest management that satisfies ecological, economic and socio-cultural dimensions at different levels in rural landscapes with a long history of traditional land use (Innes et al., 2005). There are many views concerning the role of traditional land use in rural development (Syroechkovskyy, 1974; Klokov, 1997; Yamskov, 2000; Ramakrishnan, 2001; Korytnyy et al., 2004). Nevertheless, the village with its traditional zoning to satisfy the need of goods and services is a characteristic feature (e.g., Sporrong, 1998).We regard the traditional village system (TVS) in the Ukrainian Carpathians as an integral socio-cultural component (a sub-system) of forest landscapes. To evaluate the role of the traditional village system for implementation using published historic information, (2) gathered data describing present economic, ecological and socio-cultural development, and (3) analysed actors' needs and interests as well as their land use practices. Hence, both quantitative and qualitative methods were employed. To understand the level of compliance with the Pan-European Sustainable Forest Management discourse (e.g., Rametsteiner and Mayer, 2004) we also analysed the national forest legislation, and the regional program for rural development and forestry in the Ukrainian Carpathians.

To assess the current landscape's match with the TVS we used two main attributes as proxies for assessing sustainability, (1) spatial traditional village zoning structure (i.e. domus, hortus, ager, saltus and silva), and (2) the traditional land use associated with cultural landscapes. Regarding the first attribute we refer to the description in the study area and Fig. 1. As evidence for application of traditional land use at the present time, we applied the following main criteria: (1) types of natural resources are used by local people, (2) types of land use activity are employed, and (3) the main goods and services are produced by local land users (Yamskov, 2000; Elbakidze, 2005). Analyses of published statistical data and recent original statistics were used to quan- 
tify the status and trends of economic and socio-cultural development of the region. To understand the real life of villages, 23 expert interviews were conducted with local land users in five villages in May-August, 2006. A standardised interview manual was used that contained several groups of questions including personal data of the respondents, data about household economy, sources of income, expenses, use of natural resources, farming, public work and meetings, traditions and mobility. Statements from the interviews made with local land users in summer 2006 were then compared with the State and trends derived from public statistical data.

\subsection{Study area and people}

The Skole district (147,100 ha) in the Ukrainian Carpathians was chosen as a case study landscape. The area is situated on the north-eastern side of Eastern Carpathian Mountains in the upper part of the Dnister river basin. Forests occupy $71 \%$, agricultural land $25 \%$ and urban areas $2 \%$. All forests belong to the state. There are five state forestry enterprises (SFE), which are responsible for forest management and conduct commercial activities, and one national natural park 'Skolivsky Beskydy"' (SBNNP). The proportion of forest under the management of the SFEs is $78 \%$ and $22 \%$ of the SBNNP.

The number of inhabitants in the Skole district in 2005 was 49,438, with 13 and 87\% in urban and rural settlements, respectively, with an average population density of 33 persons/ km (Anon., 2005a,b). There are 56 settlements including 55 villages and 1 town in this district. The oldest village was founded in 1100 and the youngest one in 1842. All villages are located in the forest zones (fir-beech and spruce-beech) at altitudes from 400 to $1000 \mathrm{~m}$ above sea level.

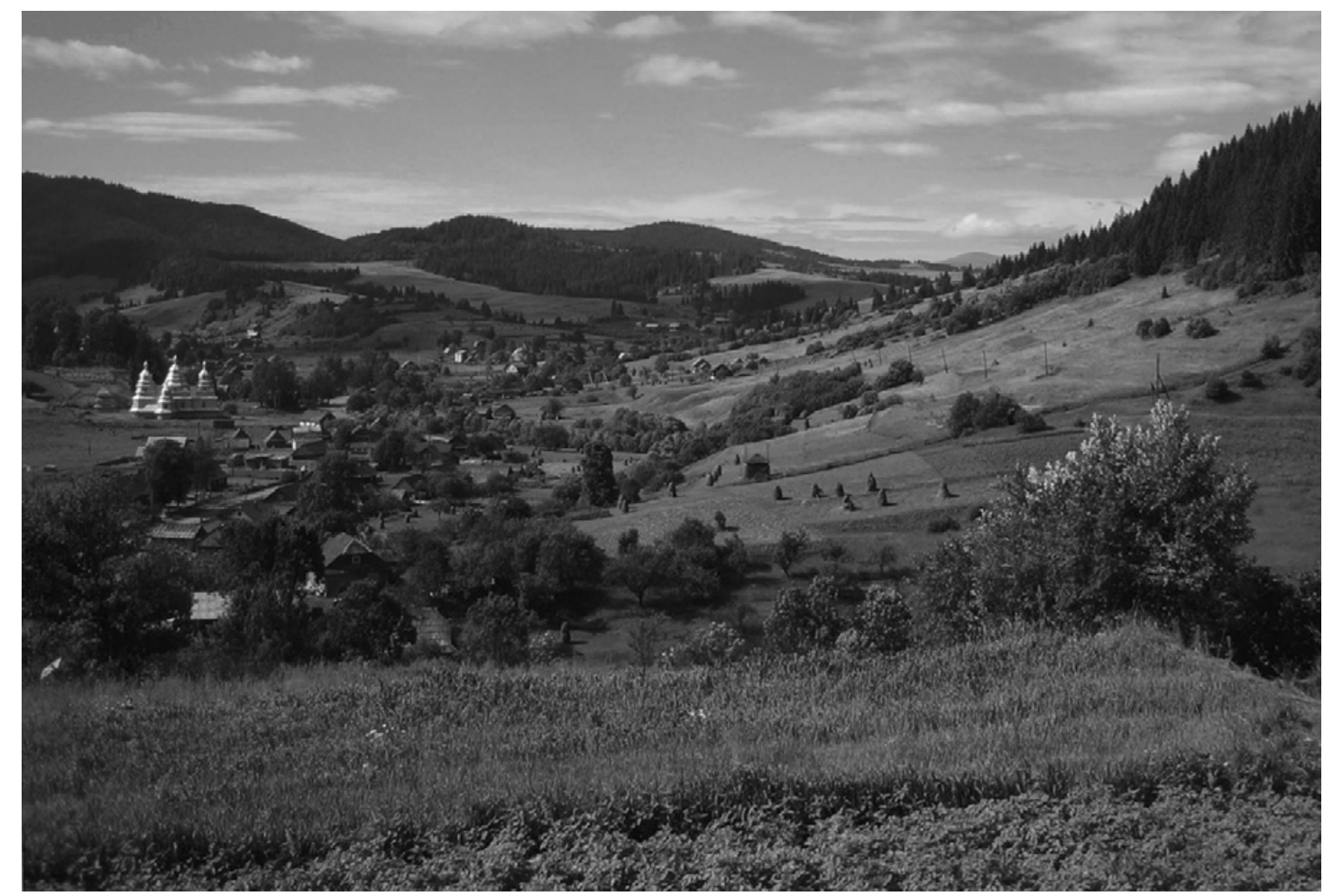

Fig. 1. The traditional village system found in Europe's forest and woodland landscapes is characterised by a centreperiphery zoning from houses, gardens, fields, mowed and grazed grasslands to forests (i.e. the ancient system with domus, hortus, ager, saltus and silva). This view of the village Volosyanka in the Skole district of Ukraine's west Carpathian Mountains illustrates this. Beginning in the left part of the picture, the church in the very village centre is surrounded by houses that are located in the bottom of the shallow valley. The private gardens have many fruit trees and shrubs. Further to the right there is a fine-grained mixture of grasslands, some individual fields of which has been mowed and have haystacks and some not yet, and fields, like the potato field in the foreground. To the right there is forest, which is grazed by cattle moving in and out along specially designed fenced trails from the farm houses in the valley bottom. In addition, above the tree line on the top of the mountains, there are open grazed pasture commons.

The Skole district has a rich history. Most people inhabiting the Skole district belongs to the Boikos (the Boikians), an ethnographic group of Ukrainian highlanders who have shaped both slopes of the middle Carpathians for centuries. The Boikos are believed to be descendants of the ancient Slavic tribe of White Croatians 
that came under the rule of the Kievan state during the reign of Prince Volodymyr I the Great (10th century) (Kyrchiv, 1978; Utrysko, 1980; Hoshko, 1983). The Boikos have kept their ancient customs and rites and much of their material culture, architecture and costume. The Skole district preserves the old type of wooden houses under the same roof as the farm buildings, the old agricultural implements, typical old churches (from 17th century), characteristic forms of costume and ornaments, as well as some old customs and terminology (Kyrchiv, 1978; Utrysko, 1980; Hoshko, 1983). Certain legends, such the story of Prince Svyatoslav's gave (10th century) and the stories about King Danylo (a famous Ukrainian King of Halychina in 13th century), indicate that the area of the Skole district played an important role in Ukrainian history (Anon., 1983). The restoration and protection of historic sites of regional and national value have been increasing since 1991, and the Skole district has been recognized as an integral part of Boyko's area in the Carpathians. The spatial structures of villages in the area still have traditional zones including: (1) built-up area, (2) gardens, (3) fields, (4) meadows and (5) forests and pasture commons, all of which satisfy different needs of land users (Fig. 1).

\section{Results}

\subsection{Development of forest landscapes in the Skole district}

The dynamic history of the Carpathian Mountain region with a range of different management paradigms has influenced the forest landscape in many dimensions. Understanding these legacies of the past is an important starting point for the implementation of sustainable forest management in this ecologically and socio-culturally diverse region. Considerable deforestation of the Eastern Carpathians took place about 7000 years ago when the mountains came under the influence of primitive agricultural activity. In this pre-agricultural period, the Skole area was populated predominantly by Slavic tribes, which were engaged in hunting, fishing and gathering since the mid-Neolithic period. In the times of the Kyivan Rus (10-11th century) and the Halych-Volyn' Principality (13-14th century), agricultural activity in Skole was small-scale. It was centred on the fortified towns and monasteries, which appeared along the trade routes that went through the Skole district's Stryj-San Highland. During that time, 8 villages, or 13\% of total number of villages in Skole, were founded (Anon., 1983; Hrushevsky, 1995a,b; Trokhimchuk, 1968; Kalynovych and Sytnyk, 2003).

An era of profound human influence on the landscape started in the 15th century when Boikos began to settle. They have since shaped landscapes for the last 500-600 years. They introduced their own traditions into land cultivation (Anon., 1983). Agricultural land development accompanied the appearance of new permanent settlements. Eighty percent of the 55 villages were founded between the 15 th and the end of the $18^{\text {th }}$ century. The traditional land use practice of that time was dependent completely on the availability of local natural resources, and on the maintenance of an ecologically balanced environment with minimal use of outside resources and energy. Chief characteristics of land use were: (1) use of a two field rotation system; (2) combination of tillage and livestock production within one farmstead; (3) division of land into interchangeable plots and sowing by shifts; (4) use of mechanical devices to cultivate the land and to control weeds; (5) protection of the soil from erosion by means of special ploughing methods (Utrysko, 1980; Kyrchiv, 1978). Local people depended completely on the availability of local natural resources and maintained these traditional land uses almost until the 18th century. The agricultural and forestry practices of that time were to a certain extent a prototype of an environmental-friendly and locally sustainable use of natural resources (Anon., 1983; Krynytskyj and Tretiak, 2003).

Historically, Poland and the Austro-Hungarian Empire, on the one hand, and Russia, on the other, divided today's Ukraine geographically into an eastern and a western multi-ethnic sphere. Continuous external political, economic and social influences have resulted in the decline of traditional forest and land use systems. The character and intensity of the use of natural resources in Skole began to change in the 19th century. One of the main reasons for this was the emancipation of serfs in 1848, which in turn led to the development of capitalism in the Halychyna, i.e. present day western Ukraine. The agricultural cultivation of land intensified and became more widespread (Trokhimchuk, 1968; Hajda, 1998; Anon., 1983). The role of livestock production increased, especially meat, milk and hide and sheep fur production, since these products were in high demand on the Austrian market. To support livestock production, in the beginning of the 19th century the Austrian government passed resolutions to increase the area of mountain meadows. This caused an intensification of forest clearance combined with grazing at higher elevations. As a result of high demand for wood in Western Europe, forest industry began to develop during the 19th century. Forests were cut, and mostly exported as timber, which was transported by means of river log driving. Often only 30-35\% of the wood would arrive at its final destination (Gensiruk, 1964; Trokhimchuk, 1968). As a rule the wood harvested was not used effi- 
ciently. Many trees were left to rot in the forests. The areas cleared of forests were not reforested again. Only a small quantity of wood was processed at the same place where it was cut down (Gensiruk, 1964). The demand for spruce timber on the world market and the rapid decrease of its supplies prompted the owners of the forests to replace the natural deciduous beech forests with spruce forests. The Carpathian Mountains had thus become a source for various kinds of wood and wood products in the international market. In 1882, this tendency was legalised by the Austrian government, which passed a resolution to replace beech, silver fir and other native forests with Norway spruce forests (Gensiruk, 1964). Starting in 1874 the wood export situation improved as railroads begun to be built across the Carpathian Mountains. Large areas of beech forests were burned in order to produce potash, which was also exported. In the place of former deciduous forests, monospecific spruce forests were created because there was a great demand for spruce wood in the countries of Western Europe. Only at the end of the $19^{\text {th }}$ century were the first attempts made to reduce forest exploitation and to restore forests. In 1894, the Austrian government passed a law regulating the use of forests and instituting responsibility to care for young trees. Thus, during this period there was a significant increase in the use of natural resources, but the majority of the population in the Skole still continued to follow traditional land use practises. Only 3 villages (or 5\% of the total number of villages) were created during the 19th century (Anon., 2005a). A complete change of political, social and economic relations that had a profound influence on the ways in which natural resources were used was initiated in 1939 when the Western regions of Ukraine became part of the Soviet Union. The Soviet regime (1939-1991) had an especially disastrous impact on the local people's way of life and use of land. Private land property was expropriated, people were forced to emigrate, arable lands increased at the expense of wooded grasslands, and forestry became more intensive (Trokhimchuk, 1968).

The structure of land and forest properties changed. Forests were now owned by the State, private plots of land were merged into collective farms (kolkhozes/kolhosps). Collectivization and mechanization left no space for the traditional way of life (Trokhimchuk, 1968). The use of natural resources in Skole area during this period shifted towards industrial use of forests with spruce reforestation, which was caused by the growing importance of forestry in the Carpathians in general, and within the Skole district in particular. Livestock production became the main agricultural activity. In order to increase pasture area, forests and brushwood were cleared. Mineral and organic fertilizers, pesticides and herbicides were introduced into agricultural practice (Hajda, 1998). These changes result in reduced the diversity of structural elements such as hedgerows and pollard trees in the different zones of the traditional village system. The use of heavy agricultural technology completely also did away with manual labour and the use of horses for ploughing. Since 1991, when Ukraine became an independent state, the economic crisis during the last decade has made local people's livelihoods directly dependent on the local use of natural resources. This has involved a return to their traditional agricultural land use practices. Non-wood forest products such as mushrooms, berries, honey, medicinal herbs, floral greenery, birch sap, resin and wild game once more became a part of the social fabric and livelihood of Ukrainian culture (Bihun, 2005), especially in forest-dependent communities such as those in the Skole district. Based on this review of the environmental history of the Skole district we define five phases of cultural landscape development, which are the results of different modes of integration of land use activities under the different governance systems. These are: (1) pre-agricultural period (until the end of 13th century); (2) period of traditional extensive land use (14-18th centuries); (3) period of intensified traditional land use (19th to early 20th centuries); (4) intensive (socialist) land use period (mid to end 20th century); (5) period of extensive land use (present time) (Table 1) (Elbakidze and Angelstam, 2006).

To understand if present land use practices in the Skole district could be characterised as that of a traditional village system, we compared the main characteristics of land use activity during the period of extensive traditional land use (phases 2,3) (Table 1) with those at present time (Table 2). The present land use was studied through the field work and interviews which were conducted in summer 2006. Analysis of Table 2 clearly indicates that the present type of land use activity is similar to the traditional with some reductions in diversity of all characteristics, which is a result of evolutionary processes in land use practices.

\subsection{Comparing quantitative and qualitative data for evaluation the present socio-economic situation}

The most common statement of local land users was “ Our grandparents land and houses are becoming empty'. The field observations in the Skole district show that marginal lands of former collective farms, which are no longer used for grazing and crop production, are returning to forests due to natural ecological succession. Decreasing amounts of open land following the collapse of collective farms is a natural result of the transition from intensive agriculture during the socialist period to the extensive land use practices of local farmers at the present time. Privatisation of arable land began after the collapse of the socialist system. How- 
ever, the "'new" agricultural land distributed between local people after 1991 has been taking into account the pre-Soviet ownership patterns. This past legacy is of exceptionally high significance for people in the Western part of Ukraine where the old generation still has strong feelings of ownership and memories about unjust political and social events, which often brought them to economic, social and cultural ruin. This is still the main subject of conversation when meeting the old generation in the villages. However, at present time it is not profitable for the local people to manage their land, and they are escaping abroad to find jobs.

Table 1. Historical development of cultural landscape in Skole district in the Ukrainian Carpathian Mountains

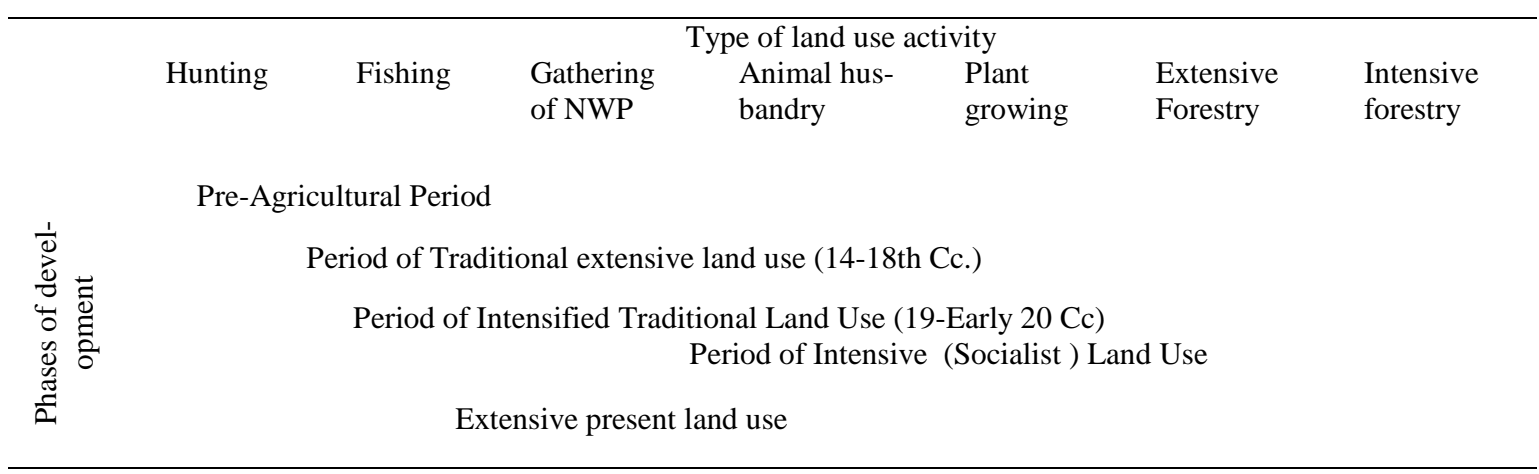

Land abandonment is thus tending to become an increasingly widespread phenomenon in the Skole district. According to official statistical data (Anon., 2005a) the number of seasonal and empty houses has increased during the last decade. In 2005, 9.6\% of villages in the district had empty houses and 36.5\% of villages had seasonal houses. Although the total numbers of empty (585, or $5 \%$ of total number of houses in the district) and seasonal (55, or $0.5 \%$ of total number) are still quite low, local people perceive this trend in villages' development as very painful. The total number of villages has not changed during the last 200 years. However, analysis of official statistic data for the last 50 years shows that the size of villages according to the number of inhabitants has varied considerably during that time.

Table 2. Main components of traditional land use activity in the part and at the present time in the Skole district (the Ukrainian Carpathians)

\begin{tabular}{|c|c|c|}
\hline Main components of land use & In the past & At present time \\
\hline Type of natural resources in use & $\begin{array}{l}\text { Arable land, meadows, non-wood } \\
\text { products, wood, wildlife }\end{array}$ & $\begin{array}{l}\text { Arable land, meadows, non-wood } \\
\text { products, wood }\end{array}$ \\
\hline Type of land use activity & $\begin{array}{l}\text { Animal husbandry, plant growing, } \\
\text { useful arts, forestry }\end{array}$ & Animal husbandry, plant growing \\
\hline Tools of land use activity & $\begin{array}{l}\text { Hands, oxen, horse, plough, scythe, } \\
\text { axe, pitchfork }\end{array}$ & $\begin{array}{l}\text { Hands, horse, plough, scythe, axe, } \\
\text { pitchfork }\end{array}$ \\
\hline Main products of farming & $\begin{array}{l}\text { Meat, milk, meal, cheese, vegetables, } \\
\text { potato, wool, cloth }\end{array}$ & Meat, milk, cheese, vegetables, potato \\
\hline
\end{tabular}

Groups of villages with inhabitants less than 100, 100-199 and 200-499 people were the most stable ones. Their numbers have changed only slightly (less then 2\%) since 1959. The most noticeable changes occurred within the groups of villages having 200-499 (increasing by 11\% in comparison with 1959) and 1000-1999 inhabitants (decreasing by $9 \%$ in comparison with their number in 1959), respectively. The second common statement was “'Young people are escaping abroad. It is so hard for us to take care of our land . . .'. Analyses the official statistic data shows that the total number of inhabitants has been permanently decreasing (15\% less) since 1970 (the socialist period) to 2005 (the transition period). At the same time a comparison of the dynamic of urban and rural population shows two opposite trends. The size of the urban population has been growing since 1970 (16\% more in 2005 then in 1970), and the rural population has been decreasing during that period (19\% less in 2005 then in 1970). According to the data of age class distribution in the population the largest groups are people of working age (28-53 year) (35\% of total number of people) and pension age (more than 55 years old) (27\% of total). In reality, however, the number of working age people is considerably lower. The reason is that while all people have permanent residence registrations in home settlements, many of them are working abroad. The third prevalent statement of local people was "The government forgot about us - no jobs, no market for our farming products, high prices for wood; without financial support from children abroad we would die'”. The number of employed people in the district is 17,600 (66\% of working age people and 49\% of total population), which includes 6043 employees of State enterprises (22.8\% of the work- 
ing age population or $12.4 \%$ of the total population) (Anon., 2005a). The main individual employers are schools (employing $6.5 \%$ of the total working age population), forestry sector (3.6\%) and health service (3.2\%). The main sources of income for local people who were interviewed by us are pension/salary and financial support by relatives from abroad. Very low incomes are derived from farming activity (mostly selling meat) and private business.

\section{Discussion}

\subsection{Sustainable forest management and the role of traditional village systems}

Previous international publications on sustainable forest management in Ukraine have focused on the attempts to reform the State forest management during the first decade of the country's independence (e.g., Nijnik and van Kooten, 2000; Nijnik and Oskam, 2004). Nordberg (2007) used an interesting comparative political science approach and concluded that the slow reform process was due to a combination of (1) interest group struggles between involved state institutions, (2) that politicians appeared to have been reluctant to take decisions that might threaten employment or the environment, and (3) that various economic interests have had significant importance, because control over the forest resource means control over an important economic asset. We have, however, not come across any studies evaluating the forest policy implementation process using a bottom-up approach founded in empirical studies of local and regional social-ecological systems, which is the approach taken in our study.

The combined use of qualitative and quantitative methods made it possible to evaluate the current dynamic of socio-cultural dimensions of the sustainable forest management concept, and to assess the extent to which this dimension of the traditional villages system has been retained in the selected case study region. After centuries of continuous coexistence between man and nature, followed by intensified management of landscapes during Austro-Hungarian and Soviet influence, the ongoing transition from planned to market economy has led to a revival of the traditional village system. This sustainability of this trend is, however, uncertain. Making use of the total economic value of forest landscape resources, including wood and non-wood products and services based on cultural values and biodiversity, is an urgent task (cf. Merlo and Croitoru, 2005).

The Ukrainian Carpathians is a good example of the complex historical development of Europe's rural landscapes (cf. Whyte, 1998). Our results indicate that the cultural landscapes associated with the traditional village system in the Skole district belongs to the second category - the organically evolved landscape - of cultural landscapes adopted by the World Heritage Committee in 1992, and included in the associated Operational Guidelines (UNESCO, 1997). This “results from an initial social, economic, administrative, and/or religious imperative and has developed into its present form by association with and in response to its natural environment. Such landscapes reflect that process of evolution in their form and component features', (UNESCO, 1997). In the context of contemporary European Union, Pan-European and many national policies (e.g., the EU Common Agricultural Policy; Anon., 2000; MCPFE, 2003) the cultural landscape of the Skole district has a high value due to its long history of development, which began in the 10th century or earlier. This landscape reflects the ancient cultural and land use traditions of the Ukrainian highlanders. The traditional village system with its characteristic zones of different land use from the centre to the periphery is, still, a basic unit of the cultural landscape. The spatial structure of the village system has not been changed considerable since the end of 18th century. There are also many cultural artifacts (like wood churches from the17th and 18th centuries, traditional wooded houses, vow crosses, etc.), and which are carefully maintained. At the same time the structural diversity of the different village zones is decreasing in the Carpathian Mountains (Angelstam et al., 2003; Kuemmerle et al., 2006).

The organically evolved landscape concept falls into two sub-categories (UNESCO, 1997). The first is the relict (or fossil) landscape in which an evolutionary process came to an end at some time in the past, either abruptly or over a period of time. Its significant distinguishing features are, however, still visible in material form. The second category is the continuing landscape. Here the landscape has an active social role in contemporary society, which is closely associated with the traditional way of life, and in which the evolutionary process of development is still in progress. At the same time, it exhibits significant material and cultural evidence of this evolution over time. These two sub-categories are relevant in countries that have been developing without cataclysmic periods in their evolution. In the post-socialist countries, like Ukraine, however, rapid and fundamental changes in political and socio-economic spheres happened at the end of the 20th century, and without a protecting social welfare system. This has resulted in the appearance of a new type of rural land- 
scapes that we call a "revived cultural landscape". A revived cultural landscape is one which resumes an active social role in contemporary society which still keeping alive their traditional knowledge in spite of political cataclysms, and in which the evolutionary process is unpredictable due to unstable land use activity. The revived landscape could be a third sub-category of an organically evolved landscape. For several reasons the maintenance of traditional village systems in the forest landscapes of the Ukrainian Carpathians is a very important prerequisite for developing sustainable forest management as it is defined in for example in the MCPFE process (Rametsteiner and Mayer, 2004; Ilavsky, 2006). Particularly important dimensions are represented by the existence of traditional villages as a base for preservation of cultural heritage and diversity, and traditional land use as a means of maintaining ecological sustainability, including species, structures and processes (Stoyko, 1991; Angelstam, 2006). The forest landscape configuration and traditional management systems in different zones of the traditional village system, which most Europeans understand as a part of their history, is an everyday reality for the people in this part of the world. This landscape is characteristic not only in parts of the Carpathian Mountains, and further to the southeast in the Balkan and Rodopi Mountains, but was common in many other European regions in the past (Angelstam, 2006; Sporrong, 1998; Vos and Meekes, 1999). Thus, loss of the authentic pre-industrial village structure characterised by a fine-grained structure of arable land and wooded grasslands is a threat to both cultural heritage and biodiversity in many rural landscapes (e.g., Ramakrishnan, 2001; Angelstam, 2006).

\subsection{The Ukrainian Carpathian villages in an European context}

The expansion of the European Union (EU) to the western border of Ukraine could bring advantages as well as disadvantages to the Ukrainian Carpathian ecoregion, now bordering four new members of the EU, namely Poland, Slovakia, Hungary and Romania. Closer integration into the EU's Common Market and some EU policies and funding will lead to the intensification of a number of threats to the natural values and long-term sustainability of the Carpathian ecoregion as a whole (cf. Angelstam, 2006). These include development of mass tourism facilities, transportation infrastructure, and agricultural intensification as well as abandonment of traditionally farmed areas (Anon., 2006). At the same time, however, increasing EU integration is also driving the adoption and implementation of a number of progressive EU laws and policies. Even if Ukraine has not been presented with the perspective of future membership in the EU, still, the country has been aligning its national laws and policies to important pieces of the EU legislation. This harmonisation process presents potentially powerful tools for nature conservation and sustainable development (Anon., 2006).

Comparing the development of cultural landscapes in the Western European countries and in the Ukrainian Carpathians shows that there are many similarities and considerable differences in rural development. In the past, traditional low intensity agriculture was the norm in Western European countries (Vos and Meekes, 1999), and the maintenance of biodiversity was an unplanned by-product (von Haaren, 2002). This phase is comparable with phases 1, 2 and 3 in cultural landscape development defined for the Skole district (Table 1). This was followed by a transition from primary to secondary economics in the West, and industrialised agriculture led to loss of biodiversity and other values (Holl and Nilsson, 1999). This is similar to the period of intensive land use during socialism (phase 4), which had a destructive impact on cultural landscapes in our case study landscape. However, the political and socio-economic systems during that phase were completely different in Europe's West and East, and created opposite initial conditions for the next phase of rural development. For example, intensification of natural resources use and disappearing cultural landscapes in the West were the result of the development of democratic societies with increased economic welfare. By contrast, in Ukraine the consequences of economic and political development during the socialist period was linked to deep political and economic crises, collapse of economy and undeveloped civil society. The present postindustrial society of the Western European countries represents a third phase- a desire to maintain 'the grandparents' landscape' which seems like a luxury for developed nations. At the present time rural development in remote areas in Ukraine like the Carpathian region, restoring and maintaining such landscapes is an absolute necessity for local villages to survive during the transition period from planned socialism to market economy (Angelstam, 2006; Elbakidze and Angelstam, 2006). Financial, social and cultural support of traditional village systems should be a milestone in a regional program of sustainable forest management designated for keeping cultural diversity and social stability of forest landscapes. The village system intactness would be a good partial indicator of success. However, the extent to which the land management in traditional village systems do maintain biodiversity also needs to be evaluated.

\subsection{Bridging emerging clefts among actors at multiple levels}

In Skole there is a realisation among several key actors that in order to satisfy all contemporary dimensions of the sustainable forest management concept, different forest users have to combine their approaches in the 
whole landscape. This requires, however, that Ukrainian forest-related policies are adapted to different regions according to their nature and history (Synyakevych and Soloviy, 2002). In addition, the policy process needs to include dialogue between policy, science and practise. Our conclusion is that there is a need to define different landscape zones that specialise in economic wood production, maintenance and restoration of ecological functions, and maintenance of socio-cultural functions (e.g., Innes and Hoen, 2005). Traditional village systems contributed to this. Regarding tourism, which is dependent on forest landscape values, there is the risk that those making money on tourism are not sufficiently aware of the need to maintain the traditional culture in terms of village system zonation of cultural landscape and cultural heritage buildings. To develop locally and regionally integrated sustainable forest management, use of both top-down and bottom-up approaches for governance are needed (Sayer and Campbell, 2004). As discussed in detail by Angelstam (1997) and Vos and Meekes (1999), this requires an inclusive holistic approach. To understand landscapes in this way requires interaction among different actors in society. This applies to policy-makers, institutions and the actual actors within one sector affecting landscapes on the one hand, and among the different sectors acting at all levels with the chosen landscape on the other. Within a given sector or policy area there are several levels (Primdahl and Brandt, 1997).

First, at the international policy level, the Convention on Biological Diversity's 'Ecosystem approach' can be used as one starting point. The ecosystem approach is a strategy for the integrated management of land, water and living resources that promotes conservation and sustainable use in an equitable way. Application of the ecosystem approach will help to reach a balance of the ecological, economic and socio-cultural objectives of the Convention. The approach should be based on the application of appropriate scientific methodologies focused on different levels of biological organisation, which encompass the essential processes, functions and interactions among organisms and their environment. It recognises that humans, with their cultural diversity, are an integral component of ecosystems. For forests, sustainable forest management as defined by Rametsteiner and Mayer (2004) can be interpreted as an example of an ecosystem approach (Angelstam et al., 2004). The European Landscape Convention (Anon., 2000) summarised most of the issues related to the maintenance of traditional village systems. Second, at the national level, policy instruments are then gradually developed, and may include legislation, information, subsidies, monitoring, vocational training, etc. However, the maintenance of natural and cultural biodiversity is usually not maintained by institutions, but rather by local people acting in different formal and informal governance systems. Consequently, several policy areas with their respective planning traditions coincide: forestry, agriculture, transport infrastructure and the energy sector, as well as regional and urban planning (Angelstam, 2006).

There are many unresolved challenges related to the integration of ecological, economic and socio-cultural dimensions of sustainable forest and woodland landscapes. We argue that the viability of forest landscapes can best be maintained with local and regional territorial approaches that target multiple complementary sectors in the economy. There is thus a need to establish arenas where people representing practice and policy can interact with both bottom-up and top-down approaches. Model Forests, Biosphere Reserves, national and regional parks, ecoregional planning, and watershed management are examples of international concepts for integrated natural resource management using the landscape as an arena for partnerships among owners, managers and local stakeholders (e.g., Sayer and Campbell, 2004; Besseau et al., 2002). For example, a Model Forest focuses on partnerships of actors in a geographic area as an approach to encouraging development of all dimensions of SFM (Anon., 2005b). The partnership should encompass all the owners, users and stakeholders within an area, and be committed to sustainable forest management. Geographically, a Model Forest encompasses a landscape large enough to represent all of the forest's uses and values. The governance structure should be representative, participative, transparent and accountable, and the program of activities should reflect the partner needs and values. Finally, there should be a commitment to knowledge-sharing and networking, from local and regional, to national and international levels. However, the effectiveness of such concepts towards satisfying economic, ecological and socio-cultural dimensions of sustainable forest management, or simply sustainable landscapes, needs to be evaluated (Axelsson and Angelstam, 2006).

\section{Acknowledgements}

We thank local people for sharing their views about life in the Skole district. Mauro Agnoletti, John Parrotta and two anonymous referees gave provided valuable comments and insight while developing this manuscript. The Swedish Institute and Marcus and Amalia Wallenberg foundation provided economic support for this study. 


\section{References}

Agnoletti, M. (Ed.), 2006. The Conservation of Cultural Landscapes. CAB International.

Andersson, F., Angelstam, P., Feger, K.-H., Hasenauer, H., Kra“uchi, N., Maºll, A., Matteucci, G., Schneider, U., Tabbush, P., 2005. A research strategy for sustainable forest management in Europe. Technical Report 5. COSTAction E25, ECOFOR, Paris, 166 pp.

Angelstam, P., 1997. Landscape analysis as a tool for the scientific management of biodiversity. Ecol. Bull. 46, 140-170.

Angelstam, P., 2006. Maintaining cultural and natural biodiversity in Europe's economic centre and periphery. In: Agnoletti, M. (Ed.), The Conservation of Cultural Landscapes. CAB International, pp. 125-143.

Angelstam, P., Boresjo“-Bronge, L., Mikusinski, G., Sporrong, U., Wa“stfelt, A., 2003. Assessing village authenticity with satellite images - a method to identify intact cultural landscapes in Europe. Ambio 33 (8), 594-604.

Angelstam, P., Elbakidze, M., 2006a. Mezhdisciplinarnyy podhod v integrirovannom menedgmente lesnyh landshaftov. In: Anon. (Eds.), Landscape Study: Theory, Methods, Regional Studies, Practice. Moscow University, Moscow, (in Russian), pp. 235-238.

Angelstam, P., Elbakidze, M., 2006b. Sustainable forest management in Europe's East and West: trajectories of development and the role of traditional knowledge. In: Parrotta, J., Agnoletti, M., Johan, E. (Eds.), Cultural Heritage and Sustainable Forest Management: The Role of Traditional Knowledge. Ministerial Conference on the Protection of Forests in Europe, vol. 2. Liaison Unit Warsaw, pp. 353-361.

Angelstam, P., Kopylova, E., Korn, H., Lazdinis, M., Sayer, J.A., Teplyakov, V., Törnblom, J., 2005. Changing forest values in Europe. In: Sayer, J.A., Maginnis, S. (Eds.), Forests in Landscapes. Ecosystem Approaches to Sustainability, Earthscan, 59-74.

Angelstam, P., Persson, R., Schlaepfer, R., 2004. The sustainable forest management vision and biodiversitybarriers and bridges for implementation in actual landscapes. Ecol. Bull. 51, 29-49.

Angelstam, P., Törnblom, J., 2004. Maintaining forest biodiversity in actual landscapes_European gradients in history and governance systems as a "landscape lab”. In: Marchetti, M. (Ed.), Monitoring and indicators of forest biodiversity in Europe-from ideas to operationality. EFI symposium 51, pp. 299-313.

Anon., 1983. Boikivshchyna, istoryko-etnografichne doslidzhennia. Lviv (in Ukrainian).

Anon., 2000. European Landscape Convention. European Treaty Series No. 176, Council of Europe.

Anon., 2005a. Statystichnyy dovidnyk po L’vivs'kiy oblasti. Lviv (in Ukrainian).

Anon., 2005b. Partnerships to success in sustainable forest management. In: International Model Forest Network Secretariat 10th Anniversary, International Development Research Centre, Ottawa.

Anon., 2006. The Carpathian Mountain ecoregion. 2012 Protected areas program. WWF proposal for submission to the MAVA Foundation.

Antrop, M., 2005. Why landscapes of the past are important for the future. Landscape Urban Plann. 70, 21-34.

Axelsson, R., Angelstam, P., 2006. Biosphere reserve and model forest: a study of two concepts for integrated natural resource management. In: Science for Sustainable Development-Starting Points, Critical Reflections, Proceedings from the 1st VHU Conference on Science for Sustainable Development, Va“stera ${ }^{\circ}$, Sweden, 12-14 April, 2005, pp. 31-39.

Balashenko, S., Laevskaya, E., Makarova, T., Lizgaro, V., Shcherbina, A., Grigoriev, E., Tarasenko, V., 2005. Review of Dnipro basin biodiversity legislation ensuring public participation and support. Water Quality Res. J. Canada, Monogr. Ser. 6, 68-82.

Berkes, F., Colding, J., Folke, C., 2003. Navigating Social-Ecological Systems. Cambridge University Press, Cambridge.

Besseau, P., Dansou, K., Johnson, F., 2002. The international model forest network (IMFN): elements of success. Forestry Chronicle 78, 648-654.

Bihun, Y., 2005. Principles of Sustainable Forest Management in the Framework of Regional Economic Development. Vistnyk Lvivs’kogo Unviversytetu. Seria Geografichna. 32, pp. 19-32.

Birot, Y., Paivinen, R., Angelstam, P., Herbst, P., Marchetti, M., Orlando, B., Papageorgio, A., Schenkel, Y., Schmidt, W., Jellesmark Thorsen, B., 2005. Report from the expert group on the vision and strategic objectives for the EU forest action plan. DG Agriculture.

Bourguignon, H., 2006. Enhancing the role of forests in the socio-economic development of forested African countries. Int. Forestry Rev. 8 (1), 126-129.

Elbakidze, M., 2005. Shlyahy zberezennya tradutsiynogo pryrodokorystuvannya v natsionalnyh parkah Ukrainskyh Karpat. In: Hamor, R. (Ed.), Hory I ludy. Rahiv, pp. 134-140 (in Ukrainian).

Elbakidze, M., Angelstam, A., 2006. Role of traditional villages for sustainable forest landscapes: a case study in the Ukrainian Carpathian Mountains. In: Parrotta, J., Agnoletti, M., Johan, E. (Eds.), Cultural heritage and sustainable forest management: the role of traditional knowledge. Ministerial Conference on the Protection of Forests in Europe, vol. 2. Liaison Unit Warsaw, pp. 375-384. 
European Union, 2006. Forest Action Plan, Brussels.

Forman, R.T.T., 1995. Land Mosaics. The Ecology of Landscapes and Regions. Cambridge University Press. Gensiruk, S., 1964. Lisy Ukrajinskykh Karpat ta jikh vykorystannia. Naukova dumka, Kyiv (in Ukrainian).

Gibbons, M., Limoges, C., Nowotny, H., Schwartzman, S., Scott, P., Trow, M., 1994. The New Knowledge Production. Sage Publications.

Grodzinski, M.D., 2005. Piznannya landshafty:mistze i prostir. In two volumes. Kyev, University of Kyev (in Ukrainian).

Hajda, Y., 1998. Turkivshchyna: pryroda i liudy. Uzhhorod (in Ukrainian).

Holl, A., Nilsson, K., 1999. Cultural landscape as a subject to national research programmes in Denmark. Landscape Urban Plann. 46, 15-27.

Hoshko, J. (Ed.), 1983. Boikivshchyna: istoryko-etnographichne doslidzhennia. Kiev.

Hrushevsky, M., 1995a. Materialy do istoriji suspilno-politychnykh i ekonomichnykh vidnosyn Zakhidnoji Ukrajiny. Naukove Tovarystvo imeni Shevchenka, Lviv (in Ukrainian).

Hrushevsky, M., 1995b. Istorija Ukrajiny - Rusi. Zhyttia ekonomichne, kulturne, natsionalne XIV-XVII vikiv. Kyiv (in Ukrainian).

Huntingdon, S.P., 1996. The Clash of Civilizations and the Remaking of World Order. The Free Press \& Design, London.

Ilavsky, J., 2006. 15 years of economics in transition: lessons learned and challenges ahead for the forestry sector. Working papers of the Finnish Forest Research Institute 24.

Innes, J.L., Hoen, H.F., 2005. The changing context of forestry. In: Innes, J.L., Hickey, G.M., Hoen, H.F. (Eds.), Forestry and Environmental Change: Socioeconomic and Political Dimensions. CABI Publishing, pp. 1-14.

Innes, J.L., Hickey, G.M., Hoen, H.F., 2005. Forestry and Environmental Change: Socioeconomic and Political Dimensions. CABI Publishing.

Kalynovych, N., Sytnyk, O., 2003. Istorija zaselennia Ukrajinskykh Karpat. In: Ekolohichni problemy Karpatskoho, regionu., Ekologichnyj, zbirnyk., Pratsi Naukovoho Tovarystva, Shevchenka 9, pp. 44-53 (in Ukrainian).

Kennedy, J.J., Ward, T.J., Glueck, P., 2001. Evolving forestry and rural development: beliefs at midpoint and close of the 20th century. Forest Policy Econ. 3, 81-95.

Klokov, K., 1997. Traditionnoe prirodopol'zovanie narodov Severa: kontseptsii sohraneniya I razvitia v sivremennyh usloviyah. Sant-Peterburg (in Russian).

Korytnyy, L., Kalep, L., Naprasnikov, A., Parfenov, V., Ponomarev, G., Ragulina,M., Savel'eva, I., 2004. Geograficheskyy podhod k vydeleniu territoriy traditsionnogo pridopol'zovaniya. Geografiya i prirodnye resursy 3 (in Russian).

Krott, M., Tikkanen, I., Petrov, A., Tunytsya, Y., Zheliba, Y., Sasse, V., Rykowina, I., Tunytsya, T., 2000. Policies for sustainable forestry in Belarus, Russia and Ukraine. Koninlijke Brill NV, Leiden, The Netherlands.

Krynytskyj, H., Tretiak, P., 2003. Stan lisiv Ukrajinskykh Karpat, ekologichni problemy ta perspektyvy. In: Ekologichni problemy Karpatskoho regionu. Ekologichnyj zbirnyk, Pratsi Naukovoho Tovarystva Shevchenka 9, 54-65.

Kuemmerle, T., Radeloff, V.C., Perzanowski, K., Hostert, P., 2006. Cross-border comparison of land cover and landscape pattern in Eastern Europe using a hybrid classification technique. Remote Sens. Environ. 103, 449-464.

Kyrchiv, R., 1978. Etnografichne doslidzhennia Boikivshchyny, Kiev (in Ukrainian).

Mayer, H., 1984. Die Wa“lder Europas. Gustav Fischer Verlag, Stuttgart (in German).

MCPFE, 2003. Vienna resolution 3. Preserving and enhancing the social and cultural dimensions of sustainable forest management in Europe. Fourth Conference on the Protection of Forests in Europe, Wien.

Merlo, M., Croitoru, L., 2005. Valuing Mediterranean Forests. Towards Total Economic Value. CABI Publishing.

Mikusinski, G., Angelstam, P., Sporrong, U., 2003. Distribution of deciduous stands in villages located in coniferous forest landscapes in Sweden. Ambio 33 (8), 520-526.

Nilsson, S., 2005. Experiences of policy reforms of the forest sector in transition and other countries. Forest Policy Econ. 7, 831-847.

Nilsson, S., Shvidenko, A., 1999. The Ukrainian forest sector in a global perspective. Interim Report IR-99011. International Institute for Applied Systems Analysis, Laxenburg, Austria.

Nordberg, M., 2007. Ukraine reforms in forestry 1990-2000. Forest Policy Econ. 9, 713-729.

Nijnik, M., Oskam, A., 2004. Governance in Ukrainian forestry: trends, impacts and remedies. Int. J. Agric. Resour. Governance Ecol. 3, 116-133.

Nijnik, M., van Kooten, G.C., 2000. Forestry in the Ukraine: the road ahead? Forest Policy Econ. 1, 139-151. 
Parrotta, J., Agnoletti, M., Johan, E. (Eds.), 2006. Cultural heritage and sustainable forest management: the role of traditional knowledge. Ministerial Conference on the Protection of Forests in Europe. Liaison Unit Warsaw.

Primdahl, J., Brandt, J., 1997. CAP, nature conservation and physical planning. In: Laurent, C., Bowler, I. (Eds.), CAP and the Regions: Building a Multidisciplinary Framework for the Analysis of the EUAgricultural Space. Institute National de la Recherche Agronomique, Paris, pp. 177-186.

Ramakrishnan, P.S., 2001. Ecology and Sustainable Development. National Book Trust, New Delhi.

Rametsteiner, E., Mayer, P., 2004. Sustainable forest management and Pan-European forest policy. Ecol. Bull. $51,51-57$.

Sastamoinen, O., 2005. Multiple ethics for multidimensional sustainability on forestry? Silva Carelica 49, 3753.

Sayer, J.A., Campbell, B.M., 2004. The Science of Sustainable Development: Local Livelihoods and the Global Environment. Cambridge University Press.

Sporrong, U., 1998. Dalecarlia in central Sweden before 1800: a society of social stability and ecological resilience. In: Berkes, F., Folke, C. (Eds.), Linking Social and Ecological Systems. Cambridge University Press, pp. 67-94.

Stevens, S., 1997. Conservation through Cultural Survival. Indigenous Peoples and Protected Areas. Island Press, Covelo.

Stoyko, S., 1991. Zapovidni ekosystemy Karpat. Lviv (in Ukrainian).

Synyakevych, Ih., Soloviy Ih., 2002. Modern forest policy problems in changing society. In: Scientific papers of agricultural university of Poznan. Forestry 5, 87-95.

Syroechkovskyy, E., 1974. Biologiheskie resursy Severa. Problemy osvoeniya. Moscow (in Russian).

Tornianen, T.J., Saastamoinen, O.J., Petrov, A.P., 2006. Russian forest policy in the turmoil of the changing balance of power. Forest Policy Econ. 9, 403-416.

Trokhimchuk, S., 1968. Zmina landshaftiv Stryjsko-Sanskoji Verkhovyny v Ukrajinskykh Karpatakh za istorychnyj chas. Rukopys dysertatsiji. Lviv (in Ukrainian).

Turnock, D., 2002. Ecoregion-based conservation in the Carpathians and the land-use implications. Land Use Policy 19, 47-63.

UNECE, 2005. European Forest Sector Outlook Study. United Nations Publications, Geneva.

UNESCO, 1999. Evaluations of cultural properties. International Council on Monuments and Sites (ICOMOS). WHC-99/CONF.209/INF.7. Marrakesh, Morocco.

UNESCO, 1997. Operational Guidelines. http://whc.unesco.org/en/guidelines.

Utrysko, M. (Ed.), 1980. Boikivshchyna: monohrafichnyi zbirnyk materiialiv Boikivshchynu z heohrafii, istorii, etnografii I pobutu. Philadelphia, New York.

Vos, W., Meekes, H., 1999. Trends in European cultural landscape development: perspectives for a sustainable future. Landscape Urban Plann. 46, 3-14.

von Haaren, C., 2002. Landscape planning facing the challenge of the development of cultural landscapes. Landscape Urban Plann. 60, 73-80.

Whyte, I.D., 1998. Rural Europe since 1500: Areas of retardation and tradition. In: Butlin, R.A., Dodgshon, R.A. (Eds.), An historical Geography of Europe. Oxford University Press, pp. 243-258.

Yamskov, A., 2000. Traditsionnoe prirodopol'zovanie: problemy opredeleniya i pravovogo regulirovaniya. Moscow (in Russian). 